\title{
Reliability of functioning and reserves of system, controlling movements with different coordination structure of special health group girl students in physical education process
}

\author{
Pryimakov A.A. ${ }^{1}$, Eider E. ${ }^{1}$, Nosko M.O. ${ }^{2}$, Iermakov S.S. ${ }^{3}$ \\ ${ }^{1}$ Szczecin University, Szczecin, Poland \\ ${ }^{2}$ Chernigiv National T.G. Shevchenko Pedagogical University, Chernigiv, Ukraine \\ ${ }^{3}$ Kazimierz Wielki University, Bydgoszcz, Poland
}

\begin{abstract}
Purpose: $\quad$ to study reliability of functioning and reserves of system, controlling movements with different coordination structure of special health group girl students (low health level) in physical education process.

Material: $\quad$ in the research special health group girl students $(n=136$, age $17-19)$ participated. They were divided into 2 groups - control and experimental. The program, directed to increase reliability and reserves of system controlling movements, was realized. It was based on physical exercises of complicated coordination with novelty elements, which were fulfilled under musical accompaniment. The research continued one academic year.

Results: $\quad$ in girl students with health problems we registered higher differential thresholds, when reproducing local movements in complicated conditions. They used visual and hearing feedback channels for informing brain's programming areas about made mistakes. They were worse teachable in training accurate movements. These girl students have less expressed compensation reserves under impact of hindering factors and interferences. It can be interpreted as non-specific crisscross negative response to motor functional system in case of health problems. All these determine reduction of reserve potentials of motor control system.

Conclusions: The main reserve potentials' criteria of control over different coordination structure movements are: quickness of passing to program mechanism of fine movements' regulation in stable conditions of functioning; power and effectiveness of compensatory reactions, ensuring interference immunity of system, controlling movements under interfering factors; reliability of maintaining movements' qualitative parameters in optimal range under interfering factors; reduction of sensor interconnections in stable functioning conditions.

Keywords: $\quad$ girl students, health, control, fine movements, reserve potentials, physical education.
\end{abstract}

\section{Introduction}

Increase of reliability of system, controlling movements of different coordination structure, are weakly elucidated in special literature on physical education and sports [24, 26, 37, 41]. General principles of mechanisms of movements' construction and control are reflected in a number of works [1, 5, 24, 26]. However, the problems of motor control reliability have been relatively weakly elucidated as well as reserves of system, controlling arbitrary movements in adaptation to physical loads by different age, sex and health problems people $[4,7,15$, $16]$.

It is known that increased physical activity is an important factor of motor system potentials' strengthening in physical culture and sports practicing $[3,13,14,17]$. Besides, physical activity is one of natural component of healthy life style [7, 10, 12, 30].

Reserves of movements' control system are a component of human organism's functional reserves (FR). However, they are relatively weakly elucidated from the following positions; mechanisms of reliability and quality of motor control [26, 28, 34, 35]; in the process healthy people's adaptation to physical loads $[4,16,22,39]$ and students with healthy problems [9, 15, 21, 27].

Hypothesis: raising of reliability and quality of control of different coordination structure movements in students' physical education (PE) is connected with the following: mastering of different equivalents methods of motor task's realization; perfection of interference immunity mechanisms; increase of compensatory reconstructions' quality in complicated conditions of functioning. Effect

(c) Pryimakov A.A., Eider E., Nosko M.O., lermakov S.S., 2017 doi:10.15561/20755279.2017.0201 of complicating factors and interferences, variability of motor re-switching and fatigue are leading factors of reserve potentials of motor control system and health improvement in students in the process of PE [10, 15].

The purpose of the work is to study reliability of functioning and reserves of system, controlling movements with different coordination structure of special health group girl students (low health level) in physical education process.

\section{Material and methods}

Principles of systemic approach in biology [20], theory of motor control [1, 5, 8, 24], adaptation to physical loads $[13,14]$ and etc. were the methodological basis of the researches. They became theoretical base for experiment and selection of physical exercises, covering different coordination abilities, manifested in movements of different complexity.

Participants: in the research special health group girl students ( $\mathrm{n}=136$, age 17-19) participated. They were divided into 2 groups - control and experimental. The program, directed to increase reliability and reserves of system controlling movements, was realized. It was based on physical exercises of complicated coordination with novelty elements, which were fulfilled under musical accompaniment. The research continued one academic year.

In EG we offered additional program for coordination abilities' development [10, 15]. Its base is physical exercises of increased coordination difficulty with novelty elements. We applied exercises of local, regional and global character with great number of motor re-switching [15, 32, 33, 40]. 
Difficulty of physical exercises increased at the account of changing their space, time and dynamic parameters [10, 25]:

1) Change of feet supporting area or its mobility in exercises for balance;

2) Functional deprivation of some sensor systems in mastering exercises for movements' accuracy;

3) Motor skills’ combining;

4) Combinations of walk with jumps, run and catching objects;

5) Exercises' fulfillment by signal or for limited time;

For increasing trainings' emotional character and density we used: musical accompaniment, aerobic means; dance elements; game character of exercises.

For assessment of motor control system's reserves we used a complex of methods of research [19, 25, 29, $36]$. With the help of different registration methods and pedagogic control we assessed indicators, characterizing quality of motor control [10, 31, 34, 35]: a) skipping; b) rhythmic space hand's movements as per the pre-set pattern (at $10 \mathrm{~cm}$ distance) at maximal rate; c) walking by straight line up to the pre-set benchmark (3 meters' distance) with open and closed eyes, before and after vestibular irritation; d) tennis ball throws at mobile and stationary targets at distance of 3 meters; e) shuttle run $4 \times 9$ $\mathrm{m}$ - for quickness; f) reproduction of $10 \mathrm{~cm}$ line on paper with open and closed eyes (by pensile); g) "Flamingo" test for balance.

Girl students' functional state was assessed by registration of cardio and respiratory functioning [10, 31]: heart beats rate (HBR, $\left.\mathrm{bpm}^{-1}\right)$; breathing frequency $\left(\mathrm{BF}, \mathrm{br} / \mathrm{min}^{-1}\right)$; breathing pause in Gandhi test $(\mathrm{Ct}, \mathrm{sec}$.$) ;$ maximal oxygen consumption $\left(\mathrm{VO}_{2} \max \right)$ by calculation in test PWC $_{170}$ [11]. Aerobic physical workability was determined with test $\mathrm{PWC}_{170}[11]$.

Statistical analysis: experimental material was processed with the help of standard statistical methods, with program Statistica 12.5 [2].

\section{Results}

Physical education during academic year resulted in positive changes in control over different coordination structure movements in both groups of girl students. At the same time, application of additional program made the studied indicators' changes more expressed in EG (see table 1).

Before experiment EG and CG girl students did not differ by quality of motor control. After experiment EG girl students demonstrated advantage by most of the studied indicators.

In average, physical condition indicators improved by $21.1 \pm 5.4 \%$ in EG and by $7.8 \pm 2.1 \%$ in $\mathrm{CG}$. With it,

Table 1. Indicators of motor control quality in control and experimental groups' girl students at the beginning and at the end of the research

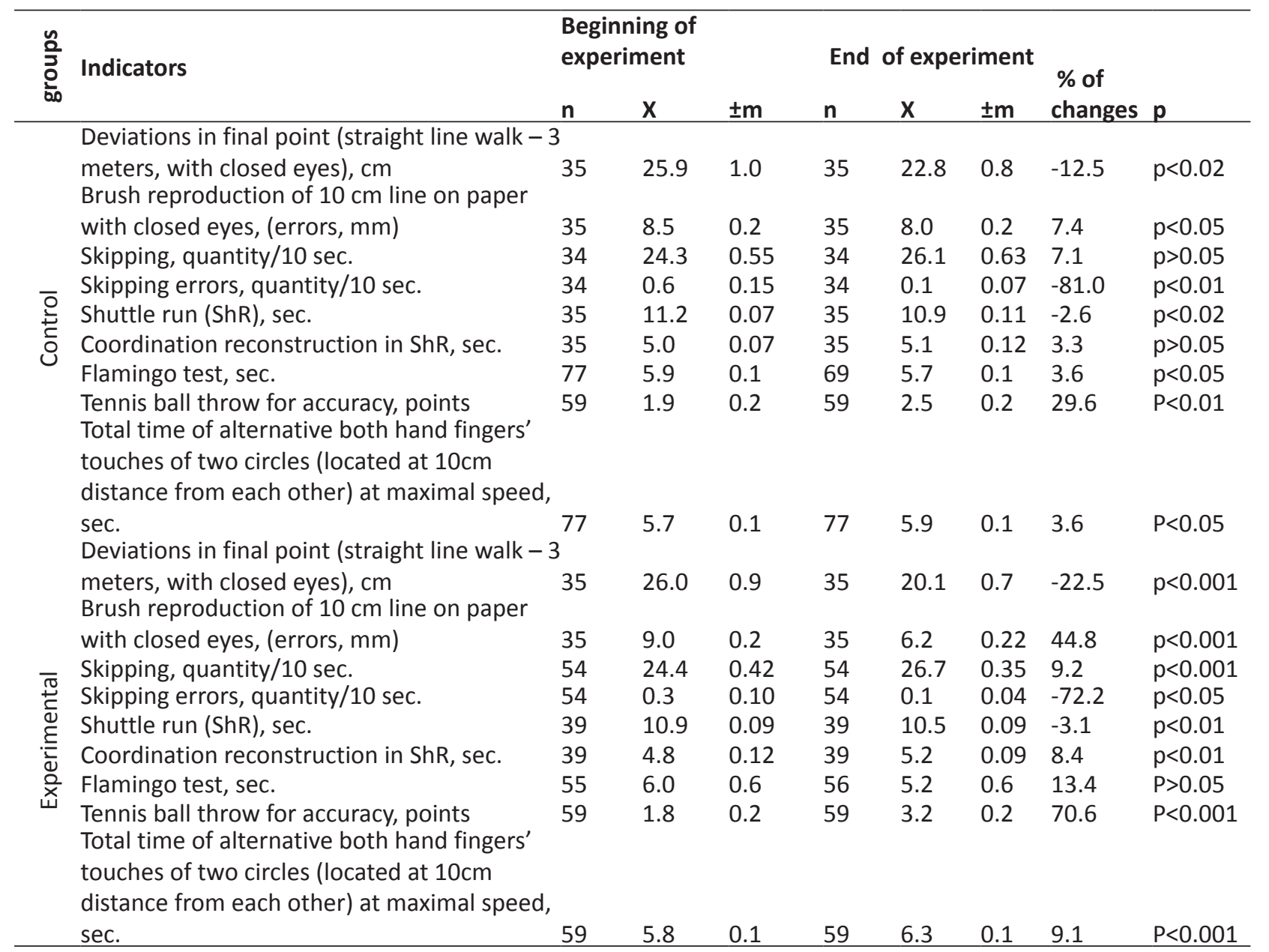


$7.5 \%$ EG girl students were moved in main health group and $3.5 \%$ - of CG girl students.

Advantage of EG girl students became noticeable by the end of experiment in fulfillment of local (space hand's movements for accuracy and quickness), regional (straight line walk for accuracy up to the pre-set bench mark, skipping, tennis ball throws to target) and global (shuttle run) movements (see table 1). These movements have different coordination structure of control $[1,8,36]$.

EG girl students improved also mastering of movements for accuracy with usage of visual feedback and in transition of program mechanism (straight line walk for accuracy, reproduction of $10 \mathrm{~cm}$ line on paper and etc.)

Analysis of cyclic loco-motor movements (walking with open and closed eyes before and after vestibular irritation) showed [10], that straight line walking for accuracy is realized, mainly, by hard program of regulation. Leading role of visual sensor system in training process is the most important in the stage of "afferent synthesis" $[18,20]$ at the beginning of training, in case of great discordance between the set program and the received results. Visual feedback channel effectively participates in correction of motor program in the stage of "afferent synthesis" - before reproduction of every exercise and in the process of its fulfillment. Hearing sensor system effectively "adjusts" motor program only in the process of its direct realization [10].

Motor perfection is accompanied by reduction of discordance errors between the formed program and results. Periodic switching off of eyesight in the process of moving increases sensitivity of proprioceptive sensor system as well as the role of visual afferentation in the following re-programming of motion. Besides, it facilitates mastering of movements for accuracy and its atomization, increasing of compensatory potentials in control system. The role of visual and hearing afferentation in correction of loco-motor moving reduces by the end of training period. With little discordance errors there happens transition to autonomous (programmed) contour of motor control with domination of proprioceptive feedback channel [10, 15]. A movement continues to be fulfilled at high quality in conditions of visual and hearing sensor systems' functional deprivation; under effect of interferences. It is in compliance with motor control conception of N.A. Bernstein [1].

In SHG students we registered higher differential thresholds in reproduction of local movements in complicated conditions. The used worse visual and hearing feedback channels for informing brain's programming areas about made errors. They manifested worse mastering of fine movements. Compensation reserves under impact of noises and interferences were weaker. It could be assessed as "non specific negative criss-cross effect" on motor functional system in case of health problems. All these determine reduction of reserve potentials of motor control system.

Analysis of correlations of EG girl students' functional state and parameters of different coordination structure movements permitted to work out assessment and prognostic models (see table 2).

Analysis of the presented models showed that with improvement of organism's functional state (by parameters of cardio functioning and external breathing) motor control quality (of fine movements) also improves. Besides, reserve potentials of motor control system strengthen, as well as reliability of main motor parameters saving under impact of interferences.

So, we found the following:

a) In EG HBR reduction in rest state is accompanied by improvement of coordination tests' results by the end of experiment: in $\mathrm{FB}(\mathrm{r}=0.598, \mathrm{p}<0.001)$, in coordination reconstructions of upper $\operatorname{limb}(\mathrm{r}=0.442, \mathrm{p}<0.01)$, in throws for accuracy to stationary $(\mathrm{r}=-0.485, \mathrm{p}<0.01)$ and moving

Table 2. Regression correlation models of some indicators of functional fitness and motor coordination in EG at the end of experiment

\begin{tabular}{|c|c|c|}
\hline Dependent indicators $(y)$ & Equations of regression & $\mathbf{r}$ \\
\hline Shuttle run, sec. & $y=8.845+0.025 \mathrm{HBR}$ & $0.598<0.001$ \\
\hline Quantity of balance deviations in "Flamingo" test & $y=0.59 F B-3.39$ & $0.461<0.01$ \\
\hline Coordination reconstructions of upper limb, quantity.10 & $y=7.983-0.027 \mathrm{HBR}$ & $0.442<0.01$ \\
\hline $\sec ^{-1}$ & $y=5>04+0.026 G T$ & $0.498<0.0001$ \\
\hline Throws at stationary target, points & $y=8.25-0.036 \mathrm{HBR}$ & $-0.485<0.0007$ \\
\hline Throws at moving target, points & $y=9.17-0.071$ & $-0.654<0.0001$ \\
\hline Coordination reconstruction in ShR & $y=1.277+0.021$ Vr HBR 3'2p I & $0.592<0.01$ \\
\hline Error in $10 \mathrm{~cm}$ line's reproduction with VC, cm & $y=10.02-0.206 \operatorname{Vr}$ HBR 3'2p & $-0.535<0.0002$ \\
\hline Throws at stationary target for accuracy, points & $\begin{array}{l}\mathrm{y}=\left(0.108 \mathrm{VO}_{2} \mathrm{max} / \mathrm{MOC}-0.033 \mathrm{HBR}\right. \\
\left.3^{\prime} r\right) \pm 1,3\end{array}$ & $0.856<0.0001$ \\
\hline \multicolumn{3}{|c|}{ 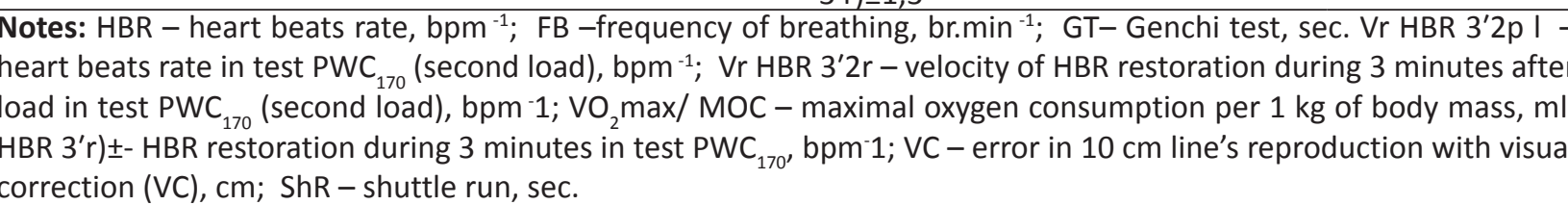 } \\
\hline
\end{tabular}


$(\mathrm{r}=-0.54, \mathrm{p}<0.001)$ targets;

b) Increase of breathing pause in Ganchi test is accompanied by increase of coordination reconstructions' quantity $(\mathrm{r}=0.498, \mathrm{p}<0.0001)$;

c) HBR reduction in response to physical load in test $\mathrm{PWC}_{170}$ is accompanied by reduction of coordination reconstructions' time in FB and vice versa $(\mathrm{r}=0.592$, $\mathrm{p}<0.01$ );

d) Increase of HBR restoration speed after physical aerobic load (in test $\mathrm{PWC}_{170}$ ) is accompanied by reduction of mistakes in reproduction of hand's local fine movements $(\mathrm{r}=-0.535, \mathrm{p}<0.0002)$;

e) with increasing of $\mathrm{VO}_{2}$ max per one $\mathrm{kg}$ of body mass and HBR reduction to $3^{\text {rd }}$ minute of recreation period after load in EG we registered improvement of throws to stationary target accuracy $(r=0.856, \mathrm{p}<0.0001-$ multiple regression model - see table 2 .

\section{Discussion}

The conducted studies showed PH and experimental program positive influence on coordination and physical condition of girl students with weak health.

In annual pedagogic cycle general mechanisms of movements' mastering were not changed. The experiment resulted in improvement of sensor-motor interconnections, reduction of sensor systems' sensitivity thresholds (to perceiving of deviations from the pre-set target with fine movements in complicated conditions). The worked out by us pedagogic program resulted also in increase of compensatory reconstructions' effectiveness (with participation of visual and hearing afferentation).

Comparison of our results with other works $[5,8,15$, 16] that general laws of local, fine movements' mastering and control are the same both for students with health problems and for healthy students [6]. SHG girl students differed insignificantly by mechanisms of mastering and control of local movements in stable external conditions from main health group students (having no health problems) $[6,9,10]$.

Most of motor tests were fulfilled in conditions of interferences; with high requirements to accuracy and at high speed. It reflected in more expressed improvement of quality and stability of motor regulation in EG. It was an evidence of compensatory mechanisms' effectiveness and power increase for saving motor system function's reliability. It witnesses about increase of motor control system's reserve potentials and is one of criteria of these reserves.

Our results showed that perfection of space fine movements' regulation realizes in the following sequence: reduction of role of external (visual and hearing) and increase in internal (proprioceptive) regulation circuit; transition to program regulation mechanism in stable conditions of functioning. It coincides with parametrical conception of motor control in standard conditions [5]. Increase of compensatory reconstructions' reliability under impact of interfering factors is one of criteria of motor control quality.

Domination of program regulation mechanism is observed in fulfillment of hand's local movements and motions in stable conditions of main movement's realization. But in conditions of interferences the role of visual and hearing feedback channels is rising for compensation of deviations and quick return to program model of movement's realization. It coincides with conception of cyclic loco-motions' control $[1,5]$.

It is characteristic that more expressed positive changes took place in movements of the highest regulation levels ( $\mathrm{C}$ and $\mathrm{D}$ by Bernstein [1]): in throwing at moving target; in shuttle run; in coordination reconstruction in ShR. We also observed positive changes in exercises, regulation of which is realized at lower levels (A and $\mathrm{B})$ : they are more stable, more programmable; more difficult to be controlled of (walking by straight line; balance in Flamingo test; skipping). They are more resistant for interferences, more stable in reproduction and are based on steady regulation programs.

Under proper organization the worked out methodic approaches to PE provisioning permit to improve physical fitness, functional state and coordination of SHG girl students. Besides, they increase reserve potentials of their motor systems and control over movements.

The corrected PE process for girl students with health problems noticeably improved motor function, increased motor system's reserve potentials; improved physical conditions.

\section{Conclusions}

As a result of our researches we found that the most important criteria of reserve potentials of local movements' control system are:

- Quickness of fine movements' mastering and transition to program mechanism of movements' regulation in stable conditions of functioning;

- Power and effectiveness of compensatory reactions, ensuring interference immunity of movements' control system under impact of interferences;

- Reliability of qualitative movements parameters' saving in optimal range under impact of interference factors;

- Reduction of sensor interconnections in movements' control system in stable functioning conditions (the principle of minimal interaction.

As on to day the following directions in solving the problem of functional reserves of movements' control system can be promising: a) study of functional reserves of different motor control levels; b) analysis of mobilized organism's reserves' structures, depending on sport functioning character; c) study of switching sequence of different levels' reserves, mechanisms of their mobilization and character of their integration in different kinds of sports; d) analysis of reserves' trainability; e) working out of monitoring and assessment flexible systems for motor system's reserves, differentiated by sex, age, character of health problems and other criteria.

\section{Conflict of interests}

The authors declare that there is no conflict of interests. 


\section{References}

1. Bernshtejn NA. O postroenii dvizhenij [On movements' construction], Moscow: Medical literature; 1947 (in Russian)

2. Borovikov VP, Ivchenko GI. Prognozirovanie $v$ sisteme STATISTICA $v$ srede Windows [Prognostication in system STATISTICA in Windows], Moscow: Finance and Statistics; 2006. (in Russian)

3. Bosenco AI, Samokih II, Strashko SV, Orlik NA, Petrovsky EP. Evaluation of junior courses students' level of mobilization of functional backlogs at the dosed physical activities at the pedagogical university. Pedagogics, psychology, medicalbiological problems of physical training and sports, 2013;11:3-9. doi:10.6084/m9.figshare.815867

4. Golubev VN, Davidenko DN, Mozzhukhin AS, Shabanov AI. Ocenka funkcional'nykh rezervov v sisteme upravleniia dvizheniem [Assessment of functional reserves in motor control system]. In: Sistemnye mekhanizmy adaptacii $i$ mobilizacii funkcional'nykh rezervov organizma $v$ processe dostizheniia vysshego sportivnogo masterstva [Systemic mechanisms of adaptation and mobilization of organism's functional reserves in the process of achievement of highest sportsmanship], Leningrad; 1987. P. 12-18. (in Russian)

5. Gurfinkel' BC, Levik IuS. Central'nye programmy i mnogoobrazie dvizhenij [Central programs and variety of movements] In: Mit'kin AA, Pik G. (Ed.) Upravlenie dvizheniiami [Control of movements], Moscow: Science; 1990. P. 32-41. (in Russian)

6. Dovgich OO. Vdoskonalennia koordinacijnikh zdibnostej studentiv na zaniattiakh z fizichnogo vikhovannia [Perfection of students' coordination at physical education lessons]. Teoriia i praktika fizichnogo vikhovannia i sportu, 2001;23:41- 44. (in Ukrainian)

7. Dolzhenko L. Zakhvoriuvanist'i rukhova aktivnist' studentiv z riznimi rivniami somatichnogo zdorov'ia [Morbidity and motor functioning of students with different somatic health]. Teoriia i metodika fizichnogo vikhovannia $i$ sportu, 2004; 1: 21-23. (in Ukrainian)

8. Donskoj DD. Teoriia stroeniia dejstvij [Theory of actions' structure]. Theory and practice of physical culture, 1991; 3 : 9-13. (in Russian)

9. Docenko EN. Rezervnye vozmozhnosti sistemy upravleniia dvizheniiami razlichnoj koordinacionnoj struktury u studentok special'nogo uchebnogo otdeleniia vuza [Reserve potentials of different coordination structure movements' control system in girl students of HEE special department]. Pedagogics, psychology, medical-biological problems of physical training and sports, 2004; 4: 36-41. (in Ukrainian)

10.Docenko OM. Rozvitok koordinacijnikh zdibnostej studentok special'noi medichnoi grupi v procesifizichnogo vikhovannia. Kand. Diss. [Training of special health group girl students' coordination in the process of physical education. Cand. Diss.], K.iev; 2011 (in Ukrainian)

11.Karpman BL, Belocerkovskij ZB, Gudkov IL. Testirovanie $v$ sportivnoj medicine [Testing in sport medicine], Moscow: Physical Culture and Sport; 1988. (in Russian)

12.Kuzmin VA, Kopylov YuA, Kudryavtsev MD, Galimov GY, Iermakov S S. Substantiation of effectiveness of trainings on health related methodic for students with weakened motor fitness. Physical education of students, 2015; 19(6): 43-49. doi:10.15561/20755279.2015.0606

13. Mishchenko BC. Funkcional'nye vozmozhnosti sportsmenov [Functional potentials of sportsmen], Kiev: Health; 1990. (in Ukrainian)

14.Pavlov SE. Adaptaciia [Adaptation], Moscow: Sails; 2000. (in Russian)
15.Pryimakov AA, Docenko EN, Pryimakov EA, Eider P. Povyshenie rezervnykh vozmozhnostej sistemy upravleniia ciklicheskim tochnostnym dvizheniem u studentok special'noj medicinskoj gruppy [Increase of reserve potentials of cyclic, fine movements' control system in special health group girl students]. Visnik Chernigivs'kogo derzhavnogo pedagogichnogo universitetu, 2010;66: 321327. (in Russian)

16.Pryimakov AA, Kozetov II, Eider E. Osobennosti upravleniia dvizheniiami raznoj koordinacionnoj struktury u detej mladshego shkol'nogo vozrasta [Special aspects of different coordination structure movements' control in primary school age children]. Pedagogics, psychology, medical-biological problems of physical training and sports, 2008; 1: 123-127. (in Russian)

17.Radzievskij AR, Pryimakov A, Oleshko V, Iashchanin N. O nakoplenii, raskhodovanii i pereraspredelenii funkcional'nykh rezervov $\mathrm{v}$ organizme cheloveka [On accumulation, condumption and re-distribution of functional reserves in human organism]. Nauka volimpijskom sporte, 2002; 2: 110-119. (in Russian)

18.Rovnij AS. Sensorni mekhanizmi upravlinnia tochnisnimi rukhami liudini [Sensor mechanisms of human fine movements' control], Kharkiv, KhADIFK; 2001. (in Ukrainian)

19.Sergiienko LP. Testuvannia rukhovikh zdibnostej shkoliariv [Testing of schoolchildren's motor abilities], Kiev: Olympic Literature; 2001. (in Ukrainian)

20.Sudakov KV. Teoriia funkcional'nykh sistem [Theory of functional systems], Moscow: Science; 1996. (in Russian)

21.Iukhimenko SM. Analiz adaptacijnogo potencialu students'koi molodi [Analysis of students' adaptation potential]. Pedagogics, psychology, medical-biological problems of physical training and sports, 2007; 1: 145-147. (in Ukrainian)

22.Becker CM, Glascoff MA, Felts WM, Kent C. Adapting and using quality management methods to improve health promotion explore. The Journal of Science and Healing, 2015; 11: 222-228.

23.Bonanni M, Newton R. Test-retest reliability of the Fukuda stepping test. Physiother Res Int, 1998; 3(1): 58-68.

24.Enoka RM. Neuromechanical basis of kinesiology. Cleveland: Human Kinetics; 1994.

25.Fairclough SJ, Stratton G. Effects of a physical education intervention to improve student activity levels. Physical Education and Sport Pedagogy, 2006; 11(1): 29-44.

26.Ghez C. Introduction to the motor sytem. In E.R. Kandel and J.H. Schwartz (Ed.), Principles of Neural Science (2nd ed). New York: Elsevier, 1985; 429-442.

27.Hasl T, Axt-Gadermann M. Gesundheitsverhalten von Studierenden an der Hochschule Coburg. Prävention und Gesundheitsförderung, 2014; 9: 287. doi:10.1007/s11553014-0439-0

28.Hirtz P. Koordinative Fahigkeiten. Trainingswissenschaft. Berlin: Sportverlag; 1994; 137:148.

29.Ivashchenko OV, Yermakova TS, Cieslicka M, Muszkieta R. Discriminant analysis as method of pedagogic control of 9-11 forms girls' functional and motor fitness. Journal of Physical Education and Sport, 2015; 15 (3): 576-581.

30.Kobza M. Aktywność ruchowa a zdrowie studentów [Physical activity and health of students]. Kultura fizyczna [Physical Culture], 1999; 3-4:12-14. (in Polish)

31.Kopeikina EN, Drogomeretsky VV, Kondakov VL, Kovaleva MV, Iermakov SS. Modification of Harvard step-test for assessment of students' with health problems functional 
potentials. Physical education of students, 2016; 20(4): 4450. doi:10.15561/20755279.2016.0405

32.Moosmann K. Erfolgreiche Koordinationsspiele. Übungsformen für Schule und Verein.Wiebelsheim: Limpert; 2008.

33.Neumaier A. Koordinatives Anforderungsprofil und Koordinationstraining. Grundlagen, Analyse, Methode. Köln: Sportverlag Strauß; 2009.

34.Raczek J. Antropomotoryka [Anthropomotorics]. Warszawa: PZML, 2010. (in Polish)

35.Raczek Joachim, Władysław Mynarski, Władimir Ljach. Kszałtowanie i diagnozowanie koordynacyjnych zdolności motorycznych [Shaping and diagnosis of coordination motor abilities], Katowice; 2003. (in Polish)

36. Roth K, Roth Ch. Entwicklung koordinativer Fähigkeiten. In: Baur J, Bös K, Conzelmann A, Singer R. (Ed.), Handbuch motorische Entwicklung. Schorndorf: Hofmann, 2009. P.197225.
37.Schnabel G. Bewegungsregulation als Informationsorganisation. Trainingswissenschaft. Berlin: Sportverlag, 1994.

38.Starosta Wlodzimierz. Koncepcja rozwijania zdolności motorycznych i nauczania techniki w treningu sportowym dzieci i młodzieży [The concept of the development of motor skills and teaching techniques in sports training children and youth]. Kierunki doskonalenia treningu $i$ walki sportowej - diagnostyka [Directions to improve training and combat sports - Diagnosis]. Warsaw: APE; 2004. P. 43-48. (in Polish)

39.Varela-Mato V, Clemes S, Cancela-Carral J. Physical activity and sitting time measured in Spanish university students. Journal of Science and Medicine in Sport, 2012; 15: 20-25.

40.Weineck J. Optimales Training. Balingen: Spitta; 2007.

41. Wilmore JH, Costill DL. Physiology of Exercise and Sport. Champaign, IL: Human Kinetics; 2005.

Information about the authors:

Pryimakov A.A.; http://orcid.org/0000-0003-0351-486X; aprim@bk.ru; Szczecin University; al. Piast 40B, Block 6, 71-065 Szczecin, Poland.

Eider E.; http://orcid.org/0000-0002-8401-6442; sekretariat.wkfipz@univ.szczecin.pl; Szczecin University; al. Piast 40B, Block 6, 71-065 Szczecin, Poland.

Nosko M.O.; http://orcid.org/0000-0001-9903-9164; pryimalnya214chnpu@meta.ua; Chernigiv National T.G. Shevchenko Pedagogical University; Str. Polubotko Getman, 53, Chernigov, 14000, Ukraine.

lermakov S.S.; http://orcid.org/0000-0002-5039-4517; sportart@gmail.com; Kazimierz Wielki University; Sport str. 2, of.209, 85-064 Bydgoszcz, Poland.

Cite this article as: Pryimakov AA, Eider E, Nosko MO, Iermakov SS. Reliability of functioning and reserves of system, controlling movements with different coordination structure of special health group girl students in physical education process. Physical education of students, 2017;2:84-89. doi:10.15561/20755279.2017.0206

The electronic version of this article is the complete one and can be found online at: http://www.sportedu.org.ua/index.php/PES/issue/archive

This is an Open Access article distributed under the terms of the Creative Commons Attribution License, which permits unrestricted use, distribution, and reproduction in any medium, provided the original work is properly cited (http://creativecommons.org/licenses/by/4.0/deed.en).

Received: 09.01.2017

Accepted: 20.01.2017; Published: 04.04.2017 